\title{
OPTIMALISASI KINERJA MESIN PENDINGIN GUNA MENJAGA KUALITAS BAHAN MAKANAN DI ATAS KAPAL MT. PUJAWATI
}

\author{
Yanu Suryaman ${ }^{a}$ dan Darul Prayogo \\ ${ }^{a}$ Taruna Program Studi Teknika STIP Jakarta \\ ${ }^{b}$ Dosen Program Studi Teknika PIP Semarang
}

\begin{abstract}
ABSTRAK
Salah satu penunjang yang sangat vital dan berhubungan dengan kesejahteraan dan kesehatan adalah Mesin Pendingin untuk menjamin kualitas dan kuantitas bahan makanan. Untuk daging dan ikan yang masih baik adalah daging dan ikan tersebut tidak lembek, tidak busuk dan saat disimpan dapat membeku seluruhnya dan bila perlu mengkristal. Agar bahan makanan tetap baik, perlu suhu penyimpanan $\pm 2^{\circ} \mathrm{C}$. Untuk penyimpanan daging dan ikan kita perlu suhu penyimpanan $\pm 15^{\circ} \mathrm{C}$.

Kurang maksimalnya kerja mesin pendingin dipengaruhi oleh berbagai faktor, baik faktor internal seperti jumlah jam kerja mesin. Untuk faktor eksternalnya hal ini sangat terkait dengan kurangnya perawatan terhadap mesin pendingin. Dalam penelitian yang penulis lakukan ada beberapa faktor yang sangat berpengaruh dalam kelancaran operasional dari mesin pendingin makanan. Adanya bunga es pada pipa-pipa evaporator merupakan masalah yang paling sering terjadi pada kerja evaporator. Hal ini terjadi bila suhu permukaan pipa bersuhu lebih rendah dari $0^{0}$ (temperatur beku air). Berikutnya adalah Kurang baiknya proses kondensasi. Saran yang diberikan dalam masalah ini yakni: Segera tutup kembali pintu ruang pendingin pada saat masuk atau keluar ruang pendingin serta melakukan pemantauan dan perawatan secara berkala terhadap jumlah freon melalui gelas duga dan minyak lumas yang terdapat pada kompresor. Agar proses kondensasi freon sempurna dan dapat mencukupi kebutuhan pendinginan, maka lakukan perawatan kondensor dengan baik. Untuk kondisi normal sebulan sekali dan apabila dalam kondisi darurat dapat dilakukan pembersihan dan pengecekan secepatnya. Melakukan pengecekan secara berkala terhadap adanya kebocoran pada instalasi mesin pendingin. Melakukan pemantauan terhadap minyak lumas yang terdapat pada kompresor serta kondisi dari oil separator agar minyak lumas tidak ikut mengalir bersama freon ke dalam sistem yang akan dapat menyebabkan terjadi endapan-endapan minyak dan gelembung-gelembung udara. Melakukan pengecekan terhadap thermo-expansion valve, jika suhu pada ruang pendingin masih tinggi setel thermo-expansion valve tersebut dengan memutar baut ke kiri atau ke kanan dan ganti dengan yang baru bila perlu
\end{abstract}

\section{Kata kunci : optimalisasi, mesin pendingin, bahan makanan}

\section{PENDAHULUAN}

Pelayaran akan dapat mencapai tujuannya dengan sukses, tepat waktu, aman dan selamat apabila seluruh prasarana dan komponen pendukung yang ada tercukupi dengan baik. Salah satu penunjang yang sangat vital dan berhubungan dengan kesejahteraan dan kesehatan adalah kualitas dan kuantitas bahan makanan. Bahan makanan itu tidak rusak atau busuk.

Agar bahan makanan tersebut tetap berkualitas dalam penyimpanan, kita perlu memiliki mesin pendingin yang memenuhi 
Optimalisasi Kinerja Mesin Pendingin Guna Menjaga Kualitas Bahan Makanan Di Atas Kapal MT. Pujawati

Yanu Suryaman dan Darul Prayogo

standar kerja. Untuk daging dan ikan yang masih baik adalah daging dan ikan tersebut tidak lembek, tidak busuk dan saat disimpan dapat membeku seluruhnya dan bila perlu mengkristal. Agar bahan makanan tetap baik, perlu suhu penyimpanan $\pm 2^{\circ} \mathrm{C}$. Untuk penyimpanan daging dan ikan kita perlu suhu penyimpanan $\pm 15^{\circ} \mathrm{C}$.

\section{METODE PENELITIAN}

Metode analisa data yang penulis gunakan dalam penelitian ini adalah deskriptif kualitatif dimana data data yang diperoleh disusun secara sistematis dan teratur, kemudian penulis membuat analisa kualitatif agar diperoleh kejelasan tentang masalah yang dilakukan dalam penelitian ini. Analisa data yang dilakukan dalam penelitian ini adalah analisa terhadap kinerja mesin pendingin. Dari penjelasan tersebut diharapkan mampu menggambarkan secara keseluruhan pokok bahasan serta pemecahan masalah penelitian ini.

\section{HASIL PENELITIAN DAN PEMBAHASAN}

Data dari mesin pendingin yang ada di kapal MT. PUJAWATI adalah :

Maker : USHIO REINETSU

Co.LTD - Japan

Tipe

: URS-2.2SSSD4

Tipe kompresor

: FAD-2SSYM ;

Semi-hermetic type

Driven dan revolusi : direct driven 1750 $\min ^{-1}$

Sumber listrik $\quad:$ AC $440 \mathrm{~V} ; 60 \mathrm{~Hz} ; 3$

phase

Tipe kondensor : UWC-204; shell and finned tube type

Bahan tube kondensor: aluminium brass

Tipe evaporator : SG-UIS2HL

Bahan cooling coil evaporator: cooper tube aluminium plate fin
Gangguan yang penulis alami selama melaksanakan praktek laut di atas kapal MT. PUJAWATI yaitu :

1. Pada tanggal 15 April 2017, kapal MT. PUJAWATI sedang sandar di pelabuhan Al-Jubayl, Saudi Arabia, seperti biasa crew kapal bekerja sesuai dengan tugas dan tanggung jawabnya masing-masing. Di suatu pagi 08.00, Masinis II dalam hal ini yang bertanggung jawab terhadap mesin pendingin makanan, melakukan pemeriksaan terhadap suhu di dalam ruang pendingin. Setelah dilakukan pemeriksaan, ditemukan bahwa terjadi peningkatan suhu yang drastis dari hari sebelumnya pada suhu ruang pendingin daging dan ikan, suhu ruang pendingin sayuran, serta suhu pada lobbi. Kemudian hasil pemeriksaan lebih lanjut dilakukan oleh Masinis II bahwa tekanan pada kompresor normal, jumlah minyak lumas yang terlihat pada gelas duga di kompresor juga dalam keadaan normal. Selanjutnya dilakukan pemeriksaan di dalam ruangan pendingin dan ditemukan banyak bunga es pada pipa-pipa evaporator.

2. Pada tanggal 26 Juli 2017 sekitar pukul 09.30, pada saat kapal MT. PUJAWATI sedang melakukan olah gerak menuju pelabuhan budge-budge di India, kapal tersebut melewati sungai yang panjang dan dalam jangka waktu yang lama. Setelah olah gerak selesai kegiatan di kamar mesin berjalan seperti biasanya, tidak lama berselang alarm pada mesin pendingin berbunyi dan kompresornya mati dengan sendirinya. Kemudian Masinis II mereset ulang mesin pendingin dengan memencet tombol reset tang terdapat di dalam kontrol panel. Setelah ditunggu beberapa saat alarm mesin pendingin kembali berbunyi dan kompresornya mati. Masinis II menemukan suhu ruangan 
pendingin tidak normal dan tidak mencapai suhu pendinginan yang diinginkan. Kemudian Masinis II melakukan pemeriksaan pada instalasi mesin pendingin makanan, diketahui bahwa permukaan bahan pendingin pada gelas duga dalam keadaan normal begitu juga dengan level minyak lumasnya dalam keadaan normal. Masinis II melakukan pengecekan pada tekanan pendingin air laut dan ditemukan bahwa tekanan air laut tidak normal, kemudian Masinis II berinisiatif langsung mematikan mesin pendingin dan membuka kondensornya. Setelah dibuka, tube-tube pada kondensor kotor sekali dan mengandung banyak lumpur yang menyebabkan proses kondensasi menjadi kurang baik.

\section{- Pembahasan}

Mesin pendingin merupakan salah satu pesawat bantu yang bekerja berdasarkan pada prinsip pemindah panas. Untuk proses penyerapan panas terjadi proses kondensasi pada kondensor dan proses penguapan pada evaporator. Dengan dipadukannya beberapa proses tersebut dalam satu sistem, maka dapat dimanfaatkan menjadi alat pendingin. Dari proses di atas, proses penguapan di evaporator yang dimanfaatkan untuk pendinginan suatu ruangan. Saat freon dalam evaporator menguap, menyerap panas di sekitar pipa kapiler evaporator, sehingga daerah di sekitar evaporator menjadi lebih dingin. Karena proses penguapan dalam evaporator terjadi terus-menerus dan sangat cepat maka keadaaan di sekitar evaporator menjadi semakin dingin. Dengan keberadaan blower yang dipasang dekat evaporator, udara dingin tersebut dihembuskan ke seluruh ruangan pendingin sehingga ruangan pendingin menjadi semakin dingin.

Kurang maksimalnya kerja mesin pendingin dipengaruhi oleh banyak faktor, baik faktor internal seperti jumlah jam kerja mesin. Untuk faktor eksternalnya hal ini sangat terkait dengan kurangnya perawatan terhadap mesin pendingin. Dalam penelitian yang penulis lakukan ada beberapa faktor yang sangat berpengaruh dalam kelancaran operasional dari mesin pendingin makanan.

1. Adanya bunga es pada pipa-pipa evaporator merupakan masalah yang paling sering terjadi pada kerja evaporator. Hal ini terjadi bila suhu permukaan pipa bersuhu lebih rendah dari $0^{0}$ (temperatur beku air). Hal ini terjadi karena adanya beberapa faktor yaitu :

a. Pintu pada ruang pendingin bahan makanan sering dibuka dalam waktu yang lama. Karena tiap kali membuka pintu ruang pendingin makanan, maka udara dingin dari dalam ruang pendingin akan keluar karena berat jenisnya lebih besar. Tempatnya yang kosong dan vakum akan diisi oleh udara luar yang lebih panas dari udara dalam ruang pendingin dan bila udara luar masuk ke ruang pendingin maka akan menyebabkan kandungan uap air yang masuk tersebut membeku pada pipa-pipa evaporator yang dapat mengakibatkan suhu ruang pendingin akan menjadi naik atau tidak normal. Sering dibukanya pintu pada ruang pendingin bisa disebabkan karena datangnya bahan-bahan makanan dari darat ke kapal yang dimasukkan ke ruang pendingin bahan makanan.

b. Ausnya ring piston pada kompresor juga menyebabkan timbulnya bunga es pada evaporator. Dengan rusaknya piston ring ataupun piston pada kompresor menyebabkan kerja kompresor dalam mengedarkan 
atau mensirkulasi freon menjadi tidak baik sehingga penyerapan panas menjadi kurang maksimal.

c. Timbulnya bunga es disebabkan oleh tidak berfungsinya pengering atau dryer. Hal ini disebabkan karena silika gel di dalam pengering sudah jenuh sehingga tidak dapat mengeringkan atau menyerap uap-uap air serta kotoran yang ikut bersirkulasi bersama freon. Uap-uap air tersebut akan membeku pada pipapipa evaporator sehingga akan membentuk bunga-bunga es dan menghambat proses penyerapan panas dari dalam ruang pendingin makanan yang menyebabkan suhunya menjadi naik.

d. Kurangnya freon yang bersirkulasi di dalam sistem karena disebabkan adanya kebocoran yang menyebabkan udara luar masuk ke dalam sistem dan ikut bersirkulasi dengan freon, apabila udara yang mengandung uap air dan kontak langsung dengan freon maka akan terjadi pembekuan uap air pada permukaan pipa-pipa evaporator yang akan didapati adanya lapisan bunga es yang akan mengakibatkan penyumbatan pada pipa-pipa evaporator dan berakibat aliran freon terhambat. Di MT. PUJAWATI ruang pendingin makanan terdiri dari kamar pendingin untuk daging dan ikan, kamar pendingin untuk buah dan sayur serta lobbi. Freon di dalam evaporator mengalami perubahan wujud dari cair menjadi gas dengan mengambil kalor dari sekitarnya sehingga di ruang pendingin bahan makanan dilengkapi dengan fan motor agar terjadi sirkulasi udara dingin yang merata ke semua bagian ruangan. Udara panas di dalam ruang pendingin dihisap oleh fan motor didorong kembali ke seluruh ruangan tempat penyimpanan bahan makanan tersebut. Di dalam ruang pendingin udara luar yang masuk ke dalam tidak boleh berlebihan atau harus dibatasi masuknya. Bila udara yang masuk terlalu banyak maka uap air yang terkandung di dalam udara luar akan mengembun dan membuat lapisan-lapisan bunga es pada pipa-pipa evaporator. Lapisan bunga es ini merupakan penghalang penyerapan panas sehingga panas di ruang pendingin tidak dapat diserap oleh freon dengan sempurna. Udara yang masuk ruang pendingin menyebabkan suhu dalam ruang pendingin menjadi naik. Tandatanda evaporator di ruang pendingin telah terjadi lapisan bunga es adalah kompresor berjalan terus tetapi suhu yang diinginkan di dalam ruang pendingin tidak tercapai serta bisa dicek secara langsung pada evaporatornya.

2. Agar freon dapat diekspansikan dan diuapkan dengan baik pada evaporator adalah freon harus dalam bentuk cair. Untuk mendapatkan Freon dalam bentuk cair, maka freon yang dalam bentuk gas hasil dari kerja kompresor harus diubah wujudnya menjadi cair yang memiliki tekanan tinggi. Proses perubahan wujud dari gas menjadi cair adalah disebut proses kondensasi. Dalam sistem mesin pendingin proses kondensasi terjadi pada kondensor. Agar proses kondensasi dapat maksimal, hal yang harus terpenuhi 
adalah kapasitas dari air pendinginnya. Untuk membuang kalor yang dikandung refrigerant yang berada di dalam tube pada kondensor. Untuk itu kondensor juga butuh perawatan seperti halnya pada evaporator agar proses kondensasi pada kondensor menjadi baik. Kurang baiknya proses kondensasi dapat disebabkan oleh beberapa faktor antara lain :

a. Terganggu proses kondensasi pada kondensor dapat disebabkan karena banyak kotoran atau lumpur yang menyebabkan pipapipa kondensor buntu sehingga proses pendinginan freon oleh air pendingin kurang maksimal. Buntunya pipa kondensor diakibatkan kurang terawatnya kondensor atau karena kapal masuk perairan dangkal seperti masuk sungai yang banyak mengandung kotoran-kotoran ataupun lumpur.

b. Tidak normalnya proses kondensasi dapat juga disebabkan oleh tekanan air laut yang masuk ke kondensor menjadi rendah. Hal ini disebabkan karena adanya kebocoran pada sistem pendingin air laut yang menuju ke kondensor sehingga pendinginan freon pada kondensor menjadi tidak normal karena freon masih panas sehingga suhu yang ingin dicapai pada ruang pendingin tidak dapat tercapai.

\section{- Pemecahan Masalah}

1. Terjadinya bunga es pada pipa evaporator adalah akibat dari banyaknya kandungan uap air di udara yang masuk ke dalam ruang pendingin karena pintu pada ruang pendingin terlalu sering dibuka. Tindakan yang dapat dilakukan dalam mengatasi terjadinya penebalan bunga es pada pipa-pipa evaporator yaitu:

a. Melakukan pemeriksaan terhadap jumlah freon yang terdapat dalam receiver. Receiver adalah suatu tempat pengumpulan cairan freon sebagai hasil kondensasi yang terjadi dalam kondensor. Jika terjadi kekurangan freon pada instalasi mesin pendingin, hal ini akan menyebabkan penyerapan panas menjadi kurang maksimal dan hembusan udara dingin yang dihembuskan oleh evaporator juga akan berkurang sehingga hal ini juga dapat menyebabkan timbulnya bunga es pada pipa-pipa evaporator. Kebutuhan freon dalam receiver tidak boleh terlalu kurang dan tidak boleh terlalu berlebihan. Harus sudah sesuai dengan tertera dalam Instruction Manual Book mesin pendingin makanan. Level freon pada instalasi mesin pendingin bisa dilihat pada gelas duga yang terdapat pada receiver yang berada di dalam kondensor. Normal atau tidaknya level freon dalam gelas duga dapat dilihat seperti gambar di bawah ini.
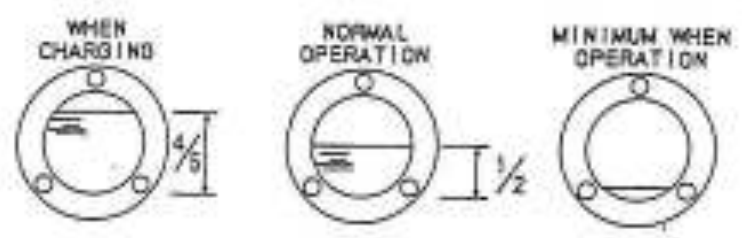

Gambar 1. Level freon pada gelas duga

b. Untuk menghilangkan bunga es pada evaporator dapat dengan menggunakan cara defrosting. Defrosting adalah pencairan bunga es pada pipa-pipa evaporator. Defrosting dapat dilakukan dengan beberapa cara :

1) Dengan menyemprotkan air panas atau air yang bertekanan rendah. 
Optimalisasi Kinerja Mesin Pendingin Guna Menjaga Kualitas Bahan Makanan Di Atas Kapal MT. Pujawati

Yanu Suryaman dan Darul Prayogo

Dalam hal ini kompresor harus dimatikan dimatikan terlebih dahulu dengan cara mematikan blower dari evaporator serta menutup katup keluaran freon dari kondensor. Kemudian air panas atau air yang bertekanan rendah disemprotkan pada pipa-pipa evaporator yang mengandung bunga es sampai bunga-bunga es pada evaporator benar-benar hilang. Jika sudah selesai, blower dihidupkan kembali dan buka katup keluaran freon dari kondensor.

2) Menggunakan pemanas elektrik dengan timer. Defrost dengan timer ini telah dirancangkan agar dalam waktu 24 jam yang terjadi 3 atau 4 kali membuat defrost.

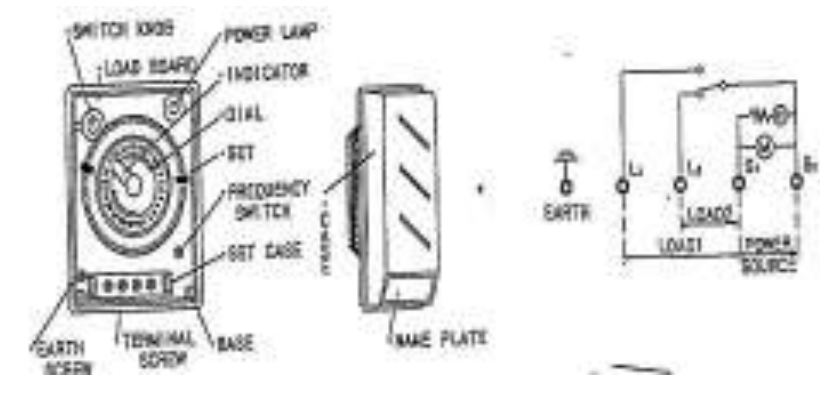

Gambar 2. Defrost timer

\section{KESIMPULAN DAN SARAN}

\section{A. Kesimpulan}

1. Terjadinya penebalan bunga es disebabkan karena kurangnya freon dalam sistem serta terjadinya kerusakan komponen-komponen pada kompresor sehingga penyerapan panas dalam ruang pendingin kurang maksimal. Hal ini mengakibatkan timbulnya bunga es pada pipa-pipa evaporator dan menyebabkan suhu pada ruang pendingin menjadi tidak optimal.

2. Proses kondensasi pada kondensor kurang maksimal dapat disebabkan karena kondensor dalam keadaan kotor sehingga akan mengganggu proses kondensasi gas freon menjadi cair. Freon yang dikondensasikan tidak dapat mencukupi kebutuhan pendinginan pada ruang pendingin sehingga suhu ruang pendingin ideal tidak dapat tercapai.

\section{B. Saran}

1. Segera tutup kembali pintu ruang pendingin pada saat masuk atau keluar ruang pendingin serta melakukan pemantauan dan perawatan secara berkala terhadap jumlah freon melalui gelas duga dan minyak lumas yang terdapat pada kompresor agar tidak terjadi keausan komponen-komponen pada kompresor dan suhu pada ruang pendingin tetap terjaga.

2. Agar proses kondensasi freon sempurna dan dapat mencukupi kebutuhan pendinginan, maka lakukan perawatan kondensor dengan baik. Untuk kondisi normal sebulan sekali dan apabila dalam kondisi darurat dapat dilakukan pembersihan dan pengecekan secepatnya.

3. Melakukan pengecekan secara berkala terhadap adanya kebocoran pada instalasi mesin pendingin agar sirkulasi gas freon dapat berjalan dengan baik.

4. Melakukan pemantauan terhadap minyal lumas yang terdapat pada kompresor serta kondisi dari oil separator agar minyak lumas tidak ikut mengalir bersama freon ke dalam sistem yang akan dapat menyebabkan terjadi endapan-endapan minyak dan gelembung-gelembung udara.

5. Melakukan pengecekan terhadap thermo-expansion valve, jika suhu pada ruang pendingin masih tinggi setel thermo-expansion valve tersebut 
dengan memutar baut ke kiri atau ke kanan dan ganti dengan yang baru bila perlu.

\section{DAFTAR PUSTAKA}

Azwar, Saifudin. 2005. Metode Penelitian. Yogyakarta : Pustaka Pelajar

Karyanto, E dan Emon Paringga. 2005. Teknik Mesin Pendingin volume 1. Jakarta : Restu Agung

Lexy, J. Moleong. 2005. Metodologi Penelitian Kualitatif. Bandung : PT. Remaja Rosda Karya

NSOS, Managemen Perawatan dan Perbaikan. Jakarta : Dirjen Perhubungan Laut

Refrigerator Provision Plant, USHIO REINETSU CO. Ltd. PT. Berlian Laju Tanker, tbk.

Simatupang, Desamen dan Ir. Tigor Sitompul. 2007. Pedoman Kerja Mesin Pendingin. STIP Jakarta 